\title{
Er was telefoon
}

Citation for published version (APA):

Coolen, L. (1998). Er was telefoon. Maastricht University. https://doi.org/10.26481/spe.19981211lc

Document status and date:

Published: 11/12/1998

DOI:

10.26481/spe.19981211lc

Document Version:

Publisher's PDF, also known as Version of record

\section{Please check the document version of this publication:}

- A submitted manuscript is the version of the article upon submission and before peer-review. There can be important differences between the submitted version and the official published version of record.

People interested in the research are advised to contact the author for the final version of the publication, or visit the DOI to the publisher's website.

- The final author version and the galley proof are versions of the publication after peer review.

- The final published version features the final layout of the paper including the volume, issue and page numbers.

Link to publication

\footnotetext{
General rights rights.

- You may freely distribute the URL identifying the publication in the public portal. please follow below link for the End User Agreement:

www.umlib.nl/taverne-license

Take down policy

If you believe that this document breaches copyright please contact us at:

repository@maastrichtuniversity.nl

providing details and we will investigate your claim
}

Copyright and moral rights for the publications made accessible in the public portal are retained by the authors and/or other copyright owners and it is a condition of accessing publications that users recognise and abide by the legal requirements associated with these

- Users may download and print one copy of any publication from the public portal for the purpose of private study or research.

- You may not further distribute the material or use it for any profit-making activity or commercial gain

If the publication is distributed under the terms of Article $25 \mathrm{fa}$ of the Dutch Copyright Act, indicated by the "Taverne" license above, 


\title{
Er was telefoon
}

\author{
Rede
}

In verkorte vorm uitgesproken bij de aanvaarding wan het ambt van deeltijd hoogleraar in de Telematica aan de Faculteit der Algemene Wetenschappen van de Universiteit Maastricht op vrijdag 11 december 1998

Door

iir. I.A.A.M. Coolen 


\section{Mijnteer de Rector Magnificus,}

Leden van het bestuur van de Stichting Wetenschapsbeoefening van de Universiteit Mastricht.

Dames en heren verbonden aan de Universiteit Maastricht, Dames en heren verbonden aan het Limburgs Universitair Centrum. En voorts allen die deze plechtigheid met uw aanwezigheid hebt willen vereren,

Zeer gewaardeerde toehoorders! 


\section{Het medium Internet}

In augustus bracht ik met mijn echtgenote de vakantie door in Canada, om precies te zijn in het geweldig moole en indrukwekkende British Colombia. De uitgestrektheid en de rust forceren een mens daar tot een lager leeftempo. Het leven is er anders dan bij ons, hoewel er ook wel eens stilstaande files voorkomen.

Eenmaal daarin beland, verlat je naar goed Canadees gebruik de auto en knoop je een gesprek aan met degene vlakbij. Zo kwamen wij in gesprek met een Canadese huisvrouw, die ons trots vertelde veelvuldig contact te hebben met mensen uit alle delen van de wereld. Zij bloek namelijk dagelijks te 'chatten' via het Internet. Op die manier had ze een Australische man ontmoet, met wie ze een half jaar later op vakantie ging. Niet virtueel, maar in levende lijve.

Het Internet was voor haar derhalve een onmisbaar communicaticmiddel geworden. Want 'chatten' bood haar een nieuwe mogelijkheid om contacten te leggen.

Het Internet is méér dan alleen het leggen van intermenselijke contacten. In de Automatisering Gids van 15 mei dit jaar heeft u kunnen lezen dat in 2002 een intelligent computerprogramma de wekelijkse vergaderingen van de ministerraad gaat ondersteunen.

Sommige leden van het kabinet zullen er meer moeite mee hebben dan anderen. Neem nu premier Kok. In februari konden wij op televisie zien hoe een klein meisje hem een aantal eenvoudige handelingen wilde laten verrichten op een PC. De muis bleek echter een onoverkomelijk obstakel. Hij probeerde nog dapper het ding als afstandsbediening te gebruiken, doch tevergeefs. Het meisje moest hem stap voor stap op weg helpen. Zodra de elelktronische snelweg een feit wordt, zoals premier Kok zelf betoogt in kamerdebatten, zal ook hij er voordeel van kunnen hebben. De stukken woor de ministerraad zullen hem langs elektronische weg bereiken. Als de bediening maar zeer eenvoudig is, geldt ook voor hem dat het Internet een onmisbare bron woor actuele informatie is. 
Het Interner heef nog een derde belangrijke functie. In oktober meldden de media dat in de Verenigde Staten twee Internet-muziekketens hebben besloten te fuseren. Hierdoor ontstaat een gigantische onderneming met samen 1,2 miljoen klanten die 'on line kumen kiezen uit 500.000 tirels. Als de verwachungen uitkomen heeft deze Internet-muziekhandel over vier jaar een omzet van 4,5 miljard dollar. Voor dit bedrije is het Internet niet meer weg te denken als een middel om handel te drijven.

Dit zijn drie willekeurige voorbeelden van het gebruik van Internet voor zaken die wij vroeger anders deden. Wat Internet voor ons betekent, kunnen wij allemaal in onze eigen omgeving zien. Nederland telt nu naar schatting één miljoen Internetgebruikers.

Zal het Internet echt een grote vlucht nemen? En, zo ja, wat zal er dan gebeuren met traditionele communicatiemiddelen als bijvoorbeeld de telefoon? De meningen daarover zijn verdeeld. Zoals u weet zijn er gelovigen en sceptici ten aanzien van de groei van het Internetgebruik.

In mijn betoog zal ik ingaan op toekomstige ontwikkelingen in de communicatiemarkt zoals ik die zie. Mijn visie is gebaseerd op zowel mijn activiteiten bij KPN, die verreweg het grootste deel van mijn tijd in beslag nemen, als op mijn activiteiten op de universiteit. Ik zal in mijn betoog met name ingaan op de consequenties van deze ontwikkelingen voor de telecommunicatie-infrastructuur. Hierbij maak ik een onderscheid tussen twee typen ontwikkelingen:

Het eerste type betreft het ontstaan van niewwe vormen wan telccommumicatie die de bestaande aanvullen. Diverse toepassingen op het Internet kunnen als voorbeeld dienen. Denk maar aan het surfen op het World Wide Web, het teleshoppen, de deelname aan discussiegroepen, de clektronische spelletjes met deelnemers op verschillende locaties en nog veel meer.

Het tweede type betreft het ontstaan van andere overdrachtsmiddelen voor reeds bestaande soorten communicatie, zoals telefonie via het Internet (IP-telefonie), radio via het Internet en elektronische post. Het gaat hier 
om het gebruik van de "elektronische snelweg" woor een groot scala aan toepassingen.

Centraal in mijn betoog staan de mogelijkheden die telecommunicatie en aanwerwante technieken te bieden hebben.

\section{De onderliggende ontwikkelingen}

\subsection{Historie}

Telecommunicatie is een vak met een rijke geschiedenis. Mensen hebben immers altijd gestreefd naar steeds snellere communicatie over steeds grotere afstanden. Men heeft altijd beseft dat een snelle informatievoorziening de macht van personen, bedrijven en regeringen vergroot.

De eerste vormen van communicatie over afstand hebben een sterke militaire component. De toneelschrijver Aeschylos (vijfde eeuw voor Christus) beschriff al dat de val van Troje op snelle wijze door de overwinnaars aan Zeus wordt doorgegeven. Via grote vuren op enkele bergtoppen word de overwinning aan de oppergod gemeld. Op deze wijze kan snel een afstand van 500 kilometer worden overbrugd. Er is hier sprake van een zeer vroege vorm van digitale optische communicatie. Een verbeterd optisch communicatiesysteem vinden we in Europa aan. het eind van de $18 \mathrm{e}$ eeuw. Dit is gebaseerd op een vinding van de Fransman Claude Chappe. Op torens worden beweegbare armen geplaatst. Iedere stand van de armen heeft een bepaalde betekenis. Op deze wijze kan teken voor teken een bericht worden doorgegeven. Dit systeem staat bekend als de luchttelegraaf. Een bericht van 25 woorden doet er zes uur over om van Straatsburg naar. Parijs te worden getransporteerd.

Met de uitvinding van het Morsetoestel in 1836 ontstaat er een nieuwe en veel snellere communicatiestructuur. Ook transatlantische communicatie wordt nu mogelijk. Hoewel deze communicatiemogelijkheid voornamelijk door overheden wordt gebruikt, ontstaat er ook een publieke dienst die voor commerciële doeleinden kan worden 
ingezet. Snelle communicatie blijkt een commercieel lucratieve faciliteit. We moeten tot 1876 wachten alworens elekmonische spraakcommunicatie haar intrede doet. De uitvinding van Alexander Graham Bell ligt hieran ten grondslag. Ook de particulier kan nu van telecommunicatie gebruik gaan maken. Met de komst van de telefoon wordt telecommunicarie nu dus ook toegepast voor de gewone intermenselijke communicatie.

Inmiddels is de telefoon niet meer te denken wit onze maatschappij. Er zijn ruim 780 miljoen telefoonaansluitingen in de wereld (bron: ITU 1998). In Europa zijn er ruim wifendertig telefoonlinen per honderd inwoners. Mondiaal zijn er ruim dertien lijnen per honderd wereldbewoners.

\subsection{Van telefonie naar datacommunicatie}

Telecommunicatie is dus onstuinig gegroeid. Deze groei heeft alleen kunnen plaatsvinden door het nut ervan: betrouwbare en snelle communicatie is onontbeerlik gebleken, zowel voor de overheid, het bedrifsleven als voor de consument.

Telecommunicatie kent inmiddels een breed scala aan toepassingen. En het verleden laat zien dat nieuwe verschijningsvormen hun intrede doen als die maar nutrig en gebruiksvriendelijk zijn. Zo is er inmiddels een wijdvertakt telefoonnet voor spraakcommunicatie. Daarnaast is er een telexnet ontstaan voor tekstcommunicatie.

In de jaren zeventig zien wij een nieuwe ontwikkeling: de computer doet zijn intrede in het communicatieveld. Aanvankelijk worden deze apparaten gebruikt binnen speciale afdelingen, bediend door specialisten. Maar als gevolg van technische ontwikkelingen verandert het gebruik ervan. De computer gaat nu ook communiceren op afstand.

Via op afstand gekoppelde terminals kan de computer zonder tussenkomst van het computercentrum rechtstreeks worden gebruikt.

Bovendien komen er de minicomputers en later zelfs de microcomputers. Uiteindelijk resulteren de technische ontwikkelingen in de PC zoals we die nu kennen.

Er ontstaat vervolgens behoefte aan telecommunicatie tussen al deze 
systemen: de datacommunicatie doet zinn intrede. Door het groeiend gebruik wan computers neemt het belang van datacommunicatie verder toe. Het gebruik van modems makt het mogelijk telefonienetten te gebruiken voor datacommunicatie.

\subsection{Van datacommunicatie naar multimedia}

Door de opkomst van Internet zijn de ontwikkelingen op het gebied van datacommunicatie nog eens wersneld. De krijgsmacht heft hierin een stimulerende rol gespeeld. Maar uiteindelijk is het de universitaire wereld geweest die de mogelijkheden van de computer maximal heeft benut on nieuwe communicatievormen en netstructuren te ontwikkelen.

Het resultaat is een multimediale communicatievorm waarin spraak, tekst, data en beeld zijn geïntegreerd. Dit is een zeer rijke vorm van communicatie: de verscheidenheid aan informatie is groot en de manier waarop de gewenste informatie gepresenteerd kan worden is zeer krachtig. Complete animaties met natuurgetrouwe afbeeldingen zijn mogelijk waarin de gebruiker zelfs driedimensional kan navigeren. Uiteraard is ook spraak mogelijk. Het Internet biedt mogelijkheden voor telefonie op cen nieuw type infrastructuur.

De invloed van Internet in de communicatiemarkt is zo groot dat de jaren negentig de geschiedenis zullen ingaan als de periode van de Internet-doorbraak. Het bijzondere is dat het openbare telecommunicatienet met zijn grote bereik deze doorbraak heeft mogelijk gemaakt.

\subsection{Ordening van de partijen}

Gezien het eerder genoemde belang van telecommunicatie, gaat men zich begin jaren 80 afvragen of de structuur die voor de aanbieders van telefonie en telex is gekozen, moet worden aangepast aan de nieuwe omstandigheden.

Op dat moment is de openbare telecommunicatie woornamelijk in handen van monopolisten, vaak staatsbedrijven. De groei van het telefoonnet, de opkomende behoefte aan datacommunicatie, en de grote 
verscheidenheid aan systemen en randapparatuur, is voor weel regeringen aanleiding om de gewenste marktordening nader te bestuderen. Dit wordt werder beschreven in het boek Athene en Arachne, bestuurtijke patronen in de topassing van netwerktechnologie (Arnbak. 1995).

De Verenigde Staten van Amerika zijn koploper in het aanpassen van de ordening. In Europa is het Verenigd Koninkrijk de eerste die aanpassingen doorvoert. Maar ook Nederland doet snel mee. In Nederland is de "Commissie Swartiouw' ingesteld om de mogelijkheden van een nieuwe ordening te bestuderen. Zij komt op 29 maart 1982 met het rapport "Taak en functie van de ptr bezien in het licht van de informatie- en telecommunicatietechnologie'. Dit rapport beschrift de combinatie van de informatietechnologie - de 'computerwereld' - , met de telecommunicatietechnologie, waar het accent op telefonie ligt. Later gaan we die combinatie 'telematica' noemen. De commissie geeft een analyse van de ontwikkelingen die ook nu nog verrassend actueel is.

De analyse gaat uit van spraak, tekst en data, waarbij de datacommunicatie voornamelijk in verband wordt gebracht met zakelijke communicatie. De technische ontwikkelingen hebben weliswaar een breder toepassingsgebied gekregen, maar de ontwikkelingsrichting van de 'Commissie Swartiouw' is correct gebleken.

De maarregelen die de commissie voorstelt zijn werwolgens verder geconcretiseerd door de commissie Steenbergen. Dat kunnen wij lezen in het rapport 'Signalen voor straks. Een nieuwe richting voor de ptt'. Dit rapport is de aanzet gebleken tot de situatie die we nu kennen. De sleutelbegrippen voor de huidige situatie zijn: privatisering, concurrentie, regulering door de overheid, en het toezicht hierop door een onafhankelijke partij. Het woord deregulering gebruik ik bewust niet. We kumen zonder meer stellen dat deze maatregelen een verdere ontwikkeling van de markt hebben bevorderd, en mede debet zijn aan het pluriforme karakter van de sector zoals die zich nu in snel tempo ontwikkelt. 


\section{De ontwikkelingen in een stroomversnelling}

\subsection{De opkomst van ICT}

De afgelopen jaren is Informatie- en Communicatietechnologie (ICT) sterk in opkomst. ICT betreft het conglomeraat aan technische doorbraken op drie gebieden:

- Computerhardware en software: er komt steeds krachtigere en goedkopere micro-elektronica vergezeld van veelzijdige, valk goedkope standaard programmatuur;

- Telecommunicatie: de bandbreedte is sterk vergroot, digitale eind tot eind communicatie is mogelijk geworden en er is een verscheidenheid aan keuzemogelijkheden om netten te realiseren;

- Audio/video: in film, TV en audio zijn de digitale technieken ver doorgedrongen. Een combinatie van digitale telecommunicatie en informatietechnologie op audio/video is daardoor mogelijk geworden.

De opkomst van ICT heeft de eerder geschetste ontwikkelingen in de communicatiemarkt nog eens in een stroonversnelling gebracht en heeft grote gevolgen woor de hele maatschappii: voor het bedrijfsleven, de overheid en woor particulieren.

\subsection{ICT en de matschappij}

Allereerst ga ik nader in op ICT en het bedrijfsleven. Deze relatie valt uiteen in twee componenten: er zijn bedrijwen die ICT producten en * diensten produceren en er zijn bedrijwen die TCT toepassen. Alhoewel Nederland veel ICT-bedrijven telt (zie studie in opdracht van EZ van juni 1998: ICT en de Economie), zal ik het daar niet over hebben. Mij gaat het om de bedrijven die ICT toepassen. Een zinvolle toepassing van ICT schept overigens wel veel extra kansen voor de leveranciers erwan.

Als we naar de productie van goederen kijken, dan zien we dat de $\| C T$ toepassingen een flexibele productie mogelijk maken. Dit wil zeggen dat 
tegen lage kosten, de productie van goederen in een grote verscheidenheid aan uitvoeringen en met een hoge kwaliteit; mogelikk wordt. Immers, via elektronische netwerken kunnen gespecialiseerde toeleveranciers de noodzakelijke informatic krijgen, zodat de halffabrikaten op tijd en op maat kunnen worden geproduceerd.

De klant kan zijn wensen kenbaar maken en die wensen worden via netwerken ara de producent doorgegeven. Dit biedt de producent een zeer flexibel en krachtig instrument om inderdaad "just in time" te produceren en te leveren.

De automobielindustrie is hiervan een goed voorbeeld. Een auto kan in zeer veel uitwoeringen en met zeer veel opties worden besteld. Productie vind plaats op basis van de specifieke klantenwensen. Er is sprake van matwerk op een platform voor massaproductie.

Deze flexibele productiewijze kan worden gezien als een logische fase in de ontwikkeling van het productieproces. Toen massaproductie haar intrede deed, gingen de kosten omlaag maar was de flexibiliteit verdwenen. Bekend is de uitspraak van de autofabrikant Henry Ford: "elke kleur is mogelijk als het maar zwart is". De huidige ontwikkelingen geven de flexibiliteir weer terug bij relatief lage kosten.

De betekenis van ICT voor bedrijven zal nog verder toenemen. De klant wordt inmiddels ook thuis de mogelijkheid geboden om zijn productwensen kenbaar te maken. We spreken dan van 'teleshoppen' of van 'electronic commerce'. Dit lijkt een logische vervolgstap. Er zijn diverse elektronische winkels bereikbaar via het Internet. Toch heeft e-commerce nog niet echt een grote omvang bereikt. Vraag matr eens in de eigen kennissenkring wie er onlangs op elektronische wijze van huis uit een bestelling heeft geplaatst. Het aantal positieve reacties hierop is meestal zeer laag. Kennelijk is er nog iets dat een doorbrak verhindert. Misschien is het fenomeen nog onvoldoende bekend, is het niet eenvoudig genoeg te bedienen, of vertrouwt men het nog niet genoeg.

Als we bedrijven intern bekijken, zien we dat de informatievoorziening op een steeds hoger peil komt. Hoog in de zin dat de informatie snel beschikbaar is op alle plaatsen waar die nodig is. De tijd dat deze 
bedrijfsinformatie alleen bestond uit rijtjes met ciffers met een toelichtende tekst, is achter de rug.

Bedrijven maken steeds meer gebruik van grafische informatie en zelfs bewegende beelden, al dan niet in driedimensionale uitwoering. Vaak kan de ontvanger zelf manipuleren met de gegevens. Door toepassing van CSCW (Computer Supported Cooperative Work) kunnen mensen vanaf verschillende locaties samen, al dan niet gelijktijdig, aan hetzelfde project werken.

Dit kan zijn het gezamenlijk werken aan een rapport maar ook het ontwerpen van een gebouw of een kledingstuk. De verschillende specialisten kunnen elk op hun eigen locatie blijven. Krachtige presentatiemiddelen maken het mogelijk realistische afbeeldingen te genereren. Speciale CSCW-software maakt het mogelijk veranderingen aan te brengen, en deze gelijktijdig en voor iedereen op hetzelfde moment zichtbaar te maken. Uiteraard maakt de software het mogelijk dat de collega's elkaar ook kunnen zien en horen.

ICT-toepassingen spelen ook een grote rol binnen de overheid en andere maatschappelijke organen. Burgers en overheid gaan anders met elkaar communiceren. Een loket met beperkte openingstijden om informatie te halen of bepaalde handelingen te verrichten, raakt uit de tijd.

Er is hier veel mogelijk. De belastingfloppy is de eerste stap geweest. De 'on line' communicatie tussen overheid en burgers staat nog in haar kinderschoenen. Een studie van KPN Research naar het gebruik ervan door gemeenten in de Verenigde Staten en West-Europa toont dat aan. Veel 'on line' gemeenten gaan niet verder dan het verstrekken wan informatie over de gemeente zelf en over toeristische attracties. Het is voor de burger nog nauwelijks mogelijk transacties te verrichten, aangiften te doen of om rechtstreeks te communiceren met de gerneente. Wel zien we dat stemmen via telecommunicatie op enkele plaatsen van start is gegaan.

Ook de consument profiteert wan ICT. Er dienen zich immers nieuwe mogelijkheden voor ontspanning en educatie aan. Denk hierbij bijvoorbeeld aan levensechte elektronische spelletjes zoals autoraces, om maar een onschuldige te noemen, en aan leren op afstand. 


\subsection{Convergentile}

Voortschrijdende ICT leidt tot integratie van computers, telecommunicatie en audio/video. De drie gebieden hebben namelijk één gemeenschappelijke noemer gekregen: zij werken met digitale informatie die door een computer wordt verwerkt. Deze informatie kan tussen de diverse plafformen worden uitgewisseld.

De ontwikkeling staat bekend onder de naam 'convergentie'. We moeten hierbij niet denken dat convergentio leidt tot éen type apparaat waarmee alles wordt gedaan. De TV blijft een andere rol spelen dan de PC of de telefoon. Het feit dat deze functies kunnen worden samengebracht in een apparaat wil nier zeggen dat dit ook altijd zal gebeuren. De apparaten diemen verschillende doelen en staan op verschillende plaatsen in een woning.

\subsection{Conclusie}

Er is een grote variëteit aan nuttige toepassingsvelden voor ICT. Gegeven de ervaring mer de groei van telecommunicatie in het verleden en gezien het nut van snelle en toegespitste communicatie, ligt een sterke groei voor de hand. Een belemmerende factor is de veelheid aan mogelijke toepassingen. Er zullen keuzes moeten worden gemaakt en die keuzes zullen moeten worden geïmplementeerd.

\section{Het kanaliseren van de ontwikkelingen}

\subsection{Complexiteit van ICT en haar toepassingen}

Een belangrijk kenmerk van ICT is dat zij in potentie zeer breed toepasbaar is. Om een brede toepassing te realiseren moet er ook inzicht zuin in de mogelijkheden die ICT biedt. Nagenoeg alle disciplines zullen ervan profiteren. Dit is de uitdaging die moet worden aanvaard. Voor niet-specialisten in het vak is het moeilijk on een goed overzicht te krijgen van de mogelijkheden en de potentiële toepassingen. ICT als zodanig is namelijk een lastig en technisch fenomeen. Bovendien heerst 
er nog altijd een behoorlijke mate van scepsis ten aanzien van ICT. Deze wordt gevoed door het snel op elkaar volgen van "hypes" en het schetsen van onwarschijnlijke futuristische toepassingen.

Met name rond het Internet speelt dit sterk. Het geloof in 'push technologie' is amper gepredikt of we moeten nu gaan geloven in 'portals".

Dit alles dwingt ons keuzes te maken wit een overweldigend aanbod van nieuwe technieken en toepassingen. Dat is zeer lastig in een wereld waar 'morgen' weer nieuwe en nog krachtiger middelen ter beschikking komen.

\subsection{Een ICT-begrippenkader is noodzakelijk}

De razendsnelle ontwikkelingen op ICT-gebied dreigen, als we niet oppassen, voor een Babylonische spraakverwarring te zorgen. I $\mathrm{k}$ hak graag aan bij de woorden van Wittgenstein, die zegt: de limieten aan minn taal zijn de limieten wan mipn wereld.

Willen we een ICT wereld creëren waarin iedereen elkaar begrijpt dan zullen we een duidelijk gedefinieerd begrippenkader moeten vaststellen. Door middel van dit ICT-begrippenkader kunnen deskundigen en toepassers met elkaar communiceren en elkaars creativiteit stimuleren. Dit begrippenkader is nu nog onvoldoende beschikbaar.

Voor het definiëren van het begrippenkader begin ik bij de ICTarchitectuur. Deze architectuur splits ik in twee grootheden, die ik aanduid mer de begrippen Infrastructuur en Toepassing. Infrastructuur omvat de netten, en Toepassing behelst de diensten die via deze netten geleverd worden.

Infrastructuur kunnen wij verwolgens definiëren als: het geheel aan middelen dat de gewenste verbindingen bewerkstelligt en dat vervolgens het transport van digitale informatie over deze verbindingen mogelijk makkt. Toepassing betreft het verrichten van de gewenste functie woor de eindgebruiker, onder gebruikmaking van die infrastructuur. Tussen Infrastructuur en Toepassing bestaat een zekere athankelijkheid maar ook een zekere keuzevrijheid.

Voor de mensen die in het vak zitten, is genoemde indeling redelijk basal. Toch blijkt de algemene hantering hiervan voor een bredere groep 
nog altijd lastig.

Neem nu het begrip telefoonnet. Dit net is ontworpen met telefonie als toepassing. In het dagelijkse spraakgebruik wordt dan ook gerefereerd aan het telefoonnet. De vele mogelijkheden van het net zijn ook gemaakt met telefonie in het achterhoofd. Maar de laatste jaren is dit net wel virgegroeid tot een telecommunicatienet, dat wil zeggen een infrastructurur die onafhankelijk staat van de toepassing telefonie.

Als wij spreken over het Internet blijkt eveneens dat de tweedeling Infrastructuur en Toepassing niet voor iedereen bekend is. Voor sommigen is Internet een communicatie-infrastructuur die is gebaseerd op het TCP/TP protocol, via welke computers van allerlei typen met elkaar kunnen communiceren. Het Internet als communicatieinfrastructuur dus.

Voor anderen is het Internet het World Wide Web met zijn onderling gekoppelde en almaar uitdjende informatiebronnen. Weer anderen denken aan 'electronic mail' en 'teleshopping'-mogelijkheden. Deze laatste zijn typische toepassingen. Het onderscheid tussen de begrippen dreigt dus te vervagen.

Op basis van de twee genoemde begrippen Infrastructuur en Toepassingen, ofte wel 'lagen', kunnen we het begrippenkader van de ICT-architectuur verder invullen. We kunnen vervolgens de specifieke bouwstenen onderscheiden. Deze zijn specialistische activiteiten binnen cen groot aantal individuele technische disciplines.

Vervolgens definiëren we het 'samenvoegen van bouwstenen tot een samenhangende structuur'. Immers, de onderlinge samenhang bepalt het gebruiksnut. Het creären van onderlinge samenhang is werk voor architecten. Deze ICT-architecten leggen de relatie tussen de wensen ten aranzen van de dienstverlening en de mogelijkheden van individuele bouwstenen. Zij spelen dezelfde rol die architecten in de huizenbouw spelen.

Deze discipline 'samenvoegen van bouwstenen' is schaars. Aan onze universiteiten spelen onderzoek en onderwijs in individuele disciplines een veel grotere rol dan de studie naar en onderricht in de samenhang. Zeker daar waar het de technische samenhang betreft. 
Ook als we de "Technologie Radar" van het ministerie van Economische Zaken bekijken, zien we dat de discipline 'archirectuur' ontbreekt in de inventarisatie wan technische disciplines waar behoefte aan is.

\subsection{Behoefte aan onderwijs}

Architecten zijn dringend nodig om snel in te spelen op mogelijkheden die ICT biedt. Ze worden nu voornamelijk in de praktijk gevormd binnen het bedrijfsleven. De bloeiende consultancy-bedrijigheid is een indicatie van de behoefte aan deze discipline. Op dit terrein is er behoefte aan versteviging van het onderwijs.

$\mathbb{I k}$ ben van mening dat op dit terrein er een grote uitdaging ligt woor het onderwijs om in deze lacune te gaan voorzien. Deze architecten zijn noodzakelijk om het begrippenkader binnen de ICT zo breed mogelijk te definiëren.

\section{Toekomst van de telecommunicatie- infrastructuur}

Wat zullen de gevolgen zijn van de snelle opkomst van ICT voor de telecommunicatie-infrastructuur? In het navolgende zal ik hierop antwoord geven, maar dan wel bezien vanuit het perspectief van de network provider en gericht op het bieden van grootschalige diensten.

\subsection{Vuistregels}

Ik baseer me hierbij op enkele vuistregels die grote elektronicaconcerns hanteren bij de grootschalige acceptatie van nieuwe apparatuur door consumenten. Ik meen dit te mogen doen omdat geheel nieuwe diensten valak bijbehorende apparaten nodig hebben.

Regel éen is dat de acceptatie als gemeen goed van een geheel nieuwe dienst de tijdsspanne wan een generatie nodig heeft, een periode van twintig tot vijfentwintig jaar dus. 
Een nieuwe technologie voor een bestaande dienst heeft een periode van circa acht jaar om erkenning de vinden.

De derde regel is dat de acceptatie van een nieuwe faciliteit voor een bestaande dienst ongeveer én jaar nodig heeft. Het gaat hier om ordes van grootte, niet om exact afgemeten tijdsintervallen.

Als we deze regels hanteren voor de ontwikkeling van ICT betekent dit, dat we een woorspelling voot over acht jaar kunnen doen, gebaseerd op het volgende:

- gelheel nieuwe diensten moeten nu al, in beperkte omvang weliswaar, zichtbaar zijn;

- nieuwe technieken voor bestaande diensten zijn nu in opkomst;

- over nieuwe faciliteiten op bestaande diensten kunnen we nog slechts gissen. Wij kunnen ons hier nog geen echt goede woorstelling van maken, gezien de relatief snelle ontwikkelingen die op dit terrein mogelijk ziin.

\subsection{Grootschalige diensten}

Toepassing van deze vuistregels op de huidige situatie betekent dat de network provider gereed moet zijn om de volgende diensten te ondersteunen via het netwerk. Ik geef hierbij een kwalitatief beeld en ga niet in op te verwachten kwantiteiten.

\section{- Spraak:}

Her gesprek blijft een belangrijk communicatiemechanisme voor de mens. Spraak groeit nog dagelijks in omvang. Het geografische bereik van de telecommunicatienetten voor spraak groeit eveneens sterk.

- Electronic mail":

Deze zal wolledig ingeburgerd raken. In 1972 is het eerste e-mail bericht verzonden door een wetenschapper die was aangesloten op het ARPA-net in de Verenigde Staten. Hier was toen sprake van een geheel nieuwe dienst, met een geheel ander karakter dan telex. E-mail gebruikte de terminals en computers die al aanwezig waren. De wijze van communicatie via e-mail heeft ook een geheel ander karakter dan die via telex. Die communicatie is formeel en 
gespecialiseerd voor wat betreft apparatuur en bediening. Denk maar eens aan de telexkamer van vroeger.

In wetenschappelijke kringen is communicatie wa e-mail sterk gegroeid. We zijn nu ruim 25 jaar verder en e-mail wordt steeds meer gebruikt. Lang niet alleen voor zakelijke communicatie. Volgens velen is deze dienst op dit moment zelfs de duurzaamste vorm van internetgebruik. Kortom: in 2007 is het gebruik wan email ner zo vanzelfsprekend als het gebruik van de telefoon nu.

- Financiële transacties:

Financiële transacties via telecommunicarie

zullen gemeengoed geworden. Het heeft een tijdje geduurd voordat we op grote schaal gingen pinnen. De stap om dit via een telecommunicatiener vanuit huis of waar dan ook te gaan doen, is een logisch vervolg. Het heeft enkele jaren nodig om ingeburgerd te raken, we zijn hiermee op weg.

- Multimediadiensten:

Multimediadiensten zijn niet zozeer een verwanging van reeds bekende diensten. Zo blijkt het dat vervanging van bijvoorbeeld een papieren krant of tijdschrift door een elektronische wariant nauwelijks succes heeft. Willen dit soort diensten een succes worden, dan moeten er ook nieuwe toepassingen komen. Die toepassingen moeten gebruik kunnen maken wan informatie die op flexibele manier door middel van tellecommunicatie ontsloten wordt. Hiervoor is allerlei krachtige programmatuur nodig. Ik denk hierbij aan kunstmatige intelligentie, software agents, zoekmechanismen, data mining, en virtual reality in $3 \mathrm{D}$.

De ontwikkeling van multimediadiensten valt onder de categorie 'geheel nieuw'. Het zal zo'n twintig tot viffentwintig jaar duren voordat deze diensten op grote schal worden gebruikt. In die tussentijd zullen er vele fantastische toepassingen komen, en er zullen er ook velen weer wegvallen. Network operators zullen voor deze toepassingen faciliteiten moten scheppen. Er zal veel creativiteit nodig zijn. Er is samenwerking nodig tussen partijen om gezamenlijk initiatieven en risicos te nemen. Ook de overheid zal hierbij een rol moeten spelen. 
Uikgande wan bovenstaande onwikkelingen zal ik nu een beeld schetsen ran de infrastructuru warover al deze nieuwe diensten aangeboden gaan worden. Ik beperk mil daarbij tot de vaste infrastructuur. Ook in de mobiele infrastructuur zijn ontwikkelingen te identificeren. Dit valt echter buiten het kader van het betoog.

\subsection{Informatiestromen zijn data gedomineerd}

De stelling dat de informatiestromen data gedomineerd zijn vereist enige uitleg, aangezien ik eerder gesteld heb dat spraak belangrijk zal blijwen. De huidige interactieve informatiestromen zijn spraak gedomineerd. Het openbare telecommunicatienet is hierop ontworpen. Het is een circuit geschakeld net dat een continue en in principe transparante tweewegverbinding realiseert tussen twee aanslluitpunten. Dit kenmerk heeft het al vanaf zijn ontstaan, in tegenstelling tot datacommunicatienetwerken die op een ander principe berusten.

Het openbare telecommunicatienet is in snel tempo gedigitaliseerd. Eerst zijin de interne verbindingen in het net digitaal gemaakt. Via het ISDN (Integrated Services Digital Network) is de digitalisering tot aan de klant een feit. Spraak wordt hierover digitaal getransporteerd in continue stromen van $64 \mathrm{kbit} / \mathrm{s}$.

Deze bitsnelheid vindt zijn oorsprong in de techniek van ruim vijfentwintig jaar geleden. Moderne technieken kunnen spraak veel efficiënter coderen. Hiervan wordt onder andere gebruik gemaakt in het GSM, en ook bij het transporteren van spraak via datacommunicatievoorzieningen zoals bij Internettelefonie.

Deze moderne technieken geven spraak dezelfde verschijningsvorm als dara. Het gaar nu door elkaar lopen: via de digitale openbare telecommunicatienerten worden behalve spraak, ook digitale data en zelfs beeld getransporteerd. Via datacommunicatievoorzieningen worden naast data en beeld ook special gecodeerde spraak en audio verzonden.

Er ontstaan nu infrastructuren die onafhankelijk zijn van informatiesoort. Het is hierdoor onbekend voor de network operator welke soort informatie via een telefoonverbinding dan wel een via een dataverbinding wordt getransporteerd.

Het openbare telecommunicatienet wordt op grote schaal gebruikt voor 
dataverkeer. Het gebruik wan Internet is hier een belangrijke oorzak wan. Dit zogenaamde IP (Internet Protocol) verkeer groelt snel. De werhouding tussen spraak- en dataverkeer is daarmee sterk in beweging. Er gaan stemmen op, met name in Californie, dat over vijt jar het aandeel van dit IP-verkeer $95 \%$ is van het totale verkeer dat over de infrastructuur wordt afgewikkeld. Of dit getal nu precies juist, is zal moeten blijken. Het is wel zo dat een dominant deel van het verkeer in 2007 inderdaad IP-verkeer zal zijn. In dit IP-verkeer zal overigens ook spraak te vinden zijn.

$\mathrm{Er}$ is nog een ontwikkeling die de dominantie wan het dataverkeer bewerkstelligt, en daar kom ik nu op.

\subsection{Breedbandige infrastructuur}

Een kenmerk van dataverkeer is dat het de transportcapaciteit gebruikt die voorhanden is. Deze transportcapaciteit stijgt sterk. De zeer snelle Local Area Networks in de werkongeving getuigen hierwan. Thuis gebruikt men steeds snellere modems en het ISDN om de snelheid op te voeren. Door die hogere snelheden rakt men gewend aan korte reactietijden. Daarnaast roept informatie weer de vraag naar extra informatie op, wat ook weer een grotere vraag naar bandbreedte met zich meebrengt.

De digitalisering van audio- en video-informatie stimuleert eveneens de behoefte aan meer bandbreedte. En niet alleen voor op zich zelf staande toepassingen als het beluisteren van muziek of het bekijken van een video. Deze audio- en video-informatie zal in 2007 een vanzelfsprekend onderdeel zijn wan allerlei informatiediensten. Convergentie maakt dit mogelijk.

Aangezien de informatiemaatschappij functioneert op basis van die informatie, is het niet verrassend dat zowel het aanbod van informatic, als de behoefte aan informatie almaar zal stijgen. Dit resulteert in een behoefte aan steeds snellere transportvoorzieningen.

De behoefte aan transportcapaciteit is een behoefte zonder eind. Er is één beperkende randvoorwaarde: de bandbreedte moet wel betaalbaar zijn!

Voor het bedriffsleven betekent dit dat op basis van een kosten/baten- 
analyse van de betrokken informatiediensten, besluiten worden genomen. Hoe goedkoper de bandbreedte des te meer toepassingen zullen er komen.

Voor particulieren ligt dit anders. Daar speelt de absolute hoogte van het bedrag in relatie tot wat men hieraan wenst te besteden een rol.

Particulieren nemen beslluiten op basis van de aantrekkelijkheid van de informatie waarover men kan beschikken. De benodigde transportcapaciteit als zodanig is geen factor waar men rekening mee wil houden. Met andere woorden, men wenst bepaalde informatiediensten en geen bandbreedte op zichzelf. Voot het transport als zodanig zal men niet weel willen betalen, voor antrekkelijke diensten worden er afwegingen gemaakt.

Hoe staat het met die breedbandigheid in de infrastructuur van 2007? De techniek op dit punt ontwikkelt zich op dit moment zeer snel. We moeten hier een onderscheid maken tussen de technielk die intern in het telecommunicatienet wordt gebruikt en de techniek die voor toegang van een gebruiker tot het telecommunicatienet wordt gebruikt In de techniek die intern in het net wordt gebruikt is een indrukwekkende ontwikkeling gaande. Via de zogenaamde DWDM-techniek (Dense Wave Division Multiplex) kunnen er verschillende kleuren licht door een glasvezel worden getransporteerd. Elke kleur kan enkele gigabits per seconde transporteren. Hierdoor wordt de capaciteit van een glasvezel gigantisch verhoogd. De kosten wan transport per bit worden drastisch verlaagd.

Ik geloof niet dat de kosten van transport naar nul gaan. Kijk maar naar de prognoses die de leveranciers zelf geven. Het is wel duidelijk dat transportcapaciteit zeer betaalbaar wordt. Hierdoor wordt de vraag naar bandbreedte extra aangezwengeld. We kunnen concluderen dat $\mathrm{er}$ in 2007 gigantische bandbreedte intern in het telecommunicatienet ter beschikking staat. Daar staat tegenover dat de behoefte ook enorm is roegenomen.

Een ander punt is de beschikbaarheid van de breedbandige toegang tot het telecommunicatienet. Voor bedrijven is dit geen punt van discussie. Daar wordt de glasvezel toegepast. Anders ligt het voor de particulieren. Het eindplaatje is hier ook helder: uiteindelijk zal de glasvezel ook bij de 
particulieren, of in ieder geval dicht bij de particulieren, witkomen. Een belangrijk facet hierbij is de ontwikkeling wan de kosten hiervan. Deze kosten kunnen laag zijn als er op grote schaal wordt gestandaardiseerd. Ik doel dan op Europese en zelfs mondiale schaal. Deze standaardisatie is tot op dit moment nog niet van de grond gekomen.

Als men het eenmaal eens wordt over standaardisatie, kan de technische ontwikkeling snel gaan. De aanleg van een dergelijk aansluimet is wel een tijdrovende en kostbare zaak. De situatie in het jaar $2007 \mathrm{kan}$ dan ook slechts in scenario's worden beschreven, de uitkomst staat nog niet vast. De particulier hoeft niet te wachten op de glasvezels voor de hogere bandbreedte. Er zijn technieken die met de huidige koperkabels een flinke bandbreedte kunnen realiseren. We praten dan over technieken als ADSL (Asymetrical Digital Subscriber Line). Deze technieken zullen ruim beschikbaar zijn in 2007 .

\subsection{Aanpassing van de architectuur van de infrastructuur}

Hierboven genoemde ontwikkelingen zullen stellig hun invloed hebben op de architectuur van het openbare relecommunicariener. Naast de traditionele circuitgeschakelde voorzieningen, zullen er in 2007 op grote schaal datavoorzieningen zijn. Voor data, en ook video, zijn pakketgeschakelde voorzieningen geünstalleerd. Deze pakketgeschakelde structuur is geoptimaliseerd voor data. Pakketschakeling is in 1967 in Engeland ontwikkeld en voor het eerst in de Verenigde Staten in het ARPA-net, toegepast. Deze techniek heeft sinds die tijd een grote ontwilkkeling meegemaakt en is de laatste jaren in een stroomversnelling gekomen. Het Internet is erop gebaseerd en is de oorzaak van die stroomversnelling. We kunnen rustig stellen dat de zogenaamde $I P-$ technologie de dominante technologie is in de datawereld. In snell tempo worden nu in de wereld voorzieningen geinstalleerd die hierop zijn gebaseerd.

In de wereld van de telecommunicatie heeft ook een ontwikkeling plaatsgevonden naar een vorm van pakketschakelen. Men voorzag de behoefte aan grotere transportcapaciteit dan het ISDN kon bieden. Deze behoefte geldt niet voor telefonie. De capaciteirsbehoefte van spraak ligt 
woor wat betreft de bowengrens redelikk vast. De extra behoefte ontstaat vanuit data- en audio/video-toepassingen. Bij het ontwerpen van de benodigde middelen voor deze toepassingen is men ook uitgekomen op pakketschakelen. Deze techniek heet ATM: Asynschronous Transfer Mode.

We zijn hiermee aangeland in een situatie warin zowel de telecommunicaticwereld als de datacommunicatiewereld een pakketgeschakelde technologie hebben. We hebben het dan over de ATM- en de IPtechnologie. Ze verschillen in concrete implementatie en ook in het type transportdiensten die ze bieden. Beiden hebben hun sterke en zwakke punten. We zullen de komende tijd zien dat ze naar elkaar toe groeien. We komen daarmee terecht in een situatie van 'the best of both worlds'. Het zal interessant zijn te zien wat dit betekent voor de leveranciers van deze technologie.

We zien op dit moment dat de traditionele network operators hun infrastructurur uitbreiden met pakketschakeling volgens ATM- en IPspecificaties. Immers, daar waar hoge bandbreedte door middel van bijvoorbeeld ADSL wordt geinstalleerd, gebeurt dit niet voor spraakcommunicatie. Breedbandige aansluitingen monden uit in pakketgeschakelde infrastructuren.

Deze infrastructuren zullen zijn gebaseerd op een combinatie van ATMen IP-eigenschappen.

\subsection{Betrouwbaarheid van de infrastructuur}

Ik kom op het punt van betrouwbaarheid van de infrastructuur. Het zal duidelijk zijn dat een infrastructuur wathet functioneren van de matschappij tan afhankelijk is, zeer betrouwbaar moet zijn. We gaan er ook zonder meer van uit dat de telefoon het altijd doet. Mocht dit onverhoopt niet het geval zijn, dan worden meteen maatregelen genomen en berichten de media er prominent over. Betrouwbarheid heeft altijd een grote rol gespeeld bij het ontwerpen van telecommunicatienetten. In de computerwereld ligt dit anders. Er is daar veel meer sprake van een 'best effort'- mechanisme. De beschikbaarheidcijfers van computernetten liggen over het algemeen veel lager dan die van telecommunicatienetten. 
Dit verschil zien we ook terug in het ontwerp van de reeds eerder genoemde ATM-en IP-technieken.

Een ander onderdeel van de betrouwbaarheid is het tijdig afhandelen van de informatieoverdracht. In 2007 is het niet meer acceptabel dat WwW ook Wachten, Wachten, Wachten kan betekenen.

Beide facetten, betrouwbarheid en tijdige afhandeling van informatie, zijn nu onvoldoende geregeld in een IP-infrastructuur. Hiervoor worden maatregelen genomen door het installeren wan een surplus asn capaciteit. Dit kan echter nooit de structurele oplossing zịn, ook niet indien deze capaciteit zeer goedkoop is. Ik zou haast zegger integendeel. Immers de behoefte aan bandbreedte is onverzadigbaar, zeker als die goedkoop is. Op dit moment lopen er acties om de IP-infrastructurur te voorzien van de benodigde eigenschappen om de betrouwbaarheid te verbeteren. Hierbij kan lering woxden getrokken uit de ontwikkelingen in de ATMwereld. Het treffen van goede betrouwbaarheidsverhogende voorzieningen is een randwoorwaarde voor de infrastructuur van de informatiemaatschappij. Deze randvoorwaarde zal in 2007 zijn ingevuld.

\subsection{Beschikbaarheid van de infrastructuur}

Het telefoonnet vervult een essentièle rol in onze huidige maatschappij. Wereldwijd zijn er ruim 750 miljoen aansluitingen. De infrastructuur voor onze informatiemaatschappij zal niet met minder aansluitingen genoegen kunnen nemen. De huidige telecommunicatie-infrastructuur zal daarom een grote rol blijven spelen. Het is de enige infrastructuur met zo'n hoge penetratiegraad.

We zullen zien dat in de technisch hoog ontwikkelde landen in die infrastructuur nieuwe mogelijkheden zullen worden gerealiseerd langs de lijnen die ik heb vermeld. Koppeling van die 'nieuwe' wereld, de ICTwereld, met de bestaande telecommunicatiewereld is een vaststaand feit. In de technisch hoog ontwikkelde landen wordt de infrastructuur verder ontwikkeld om snel de nieuwe diensten mogelijk te maken. In de zich ontwikkelende landen wordt de infrastructuur gebruikt on toegang te realiseren tot nieuwe diensten. Er is een grote mate van koppeling tussen de oude en de nieuwe infrastructuur. De techniek kan ervoor zorgen dat het niveau wan de dienstverlening is afgestemd op de zwakste schalkel 
binnen en bepalde communicatievorm.

We kunnen ervan uitgaan dat in 2007 informatiediensten over de gehele wertd knnnen en zullen worden geboden.

\subsection{Intelligent netwerk}

Er is een flinke discussie gaande over de intelligentie die de nieuwe ICT netwerken bezitten. De meningen lopen uiteen: sommigen gaan uit van een 'stupid networks', anderen van een 'intelligent network'. Met intelligentie wordt dan bedoeld de verzameling faciliteiten van een netwerk die uitgaat bowen het realiseren van een bit transport tussen opgegewen eindpunten. Deze discussie is geen discussie over het nut en de noodzalk van die extra faciliteiten. Daarover is men het wel eens. De discussie handelt over de vraag op welk niveau in de totale infrastructur die voorzieningen worden ondergebracht. Dat kan zijn op het niveau van een nerwork operator, een service provider of een information provider. De techniek laat in principe alle varianten toe. Het is een kwestie van optimaliseren en het is vooral ook een commerciẻle kwestie. De markt zal het uiteindelijk uitmaken.

Zelf ben ik van mening dat generieke functies zo laag mogelijk in de infrastructuur moeten worden ondergebracht. Op deze wijze wordt zo goed mogelijk gebruik gemalkt van de 'economies of scale". Flexibiliteit ten aanzien van wijzigende en individuele wensen moet wel worden gerealiseerd. Gezien de ontwikkelingen in de ICT-wereld, wordt dit steeds beter mogelijk, ook in grootschalige operaties. Door deze ontwikkeling komen network providers in een potentieel gunstige positie.

De commerciële krachten zullen er wel toe leiden dat bepaalde aanbieders van faciliteiten in de markt gebruik maken van "domme" verbindingen die door een network prowider worden geboden.

Dit leidt tot een situatie dat de network providers een breed palet aan faciliteiten bieden, boven op het assortiment dat nu ook al wordt geboden. Daarnast zullen er aanbieders zijn die bepaalde niches van faciliteiten voorzien. Deze zullen veelal gekoppeld zijn aan service en aan information providers die specifieke wensen hebben. 


\section{9 "Multi point"- diensten}

Als laatste richtpunt voor de infrastructuar wil ik een specifieke faciliteit noemen: de 'multi point' - verbindingen. Het huidige telecommunicatienet is ontworpen om twee willekeurige punten met elkaar te verbinden. Als er bij een bepalde dienst meer dan twee partijen zijn betrokken, ontstaat er een andere situatie. Dit treedt bijpoorbeeld op bij telefonisch vergaderen, lessen volgen via tele-educatie, virtuele projectteams et cetera.

Door speciale apparatuur aan het net te koppelen kan in deze functionaliteit worden voorzien. Toekomstige netten zullen dit als inherente mogelijkheid hebben, waardoor 'multi point'-verbindingen voor allerlei informatiediensten ter beschikking komen. Dit opent een geheel nieuwe reeks van mogelijke diensten, die ik hier verder onbesproken laat.

\section{Een nieuwe dimensie: van spraak naar ICT}

Hierboven heb ik toegelicht aan welke eisen de ICT-infrastructuur moet voldoen om de maatschappii zo veel mogelijk te laten profiteren. Tk heb een aantal richtpunten genoemd. Daarnaast heb ik aangegeven welke situatie ik over een periode van circa acht jaar verwacht.

Het zijn verwachtingen, want het succes van ICT wordt uiteindelijk bepaald door de toepassingen die de technologie mogelijk maakt. Om die toepassingen te stimuleren, moet op een groot aantal gebieden nog werk verricht worden. De vraag is of dit ook gaat gebeuren.

Ik ben hier optimistisch over, maar voorzichtigheid blifft geboden. Ik zal dit toelichten.

Het huidige kabinet kondigt aan het een en ander van plan te zijn. Zo is in het regeerakkoord vermeld welke woornemens het koestert om ICTtoepassingen te stimulleren. Er zijn aanzienlijke investeringen in de kennisinfrastructuur aangekondigd. Het kabinet wil ICT ook structureel inbedden in het onderwijs. En uiteraard wordt de elektronische snelweg genoemd. 
Echter, het kabinet kondigt in het regeeraklkoord geen concrete activiteiten aan. Ook in de troonrede wordt geen melding gemaakt van concrete acties om ICT-toepassingen te stimuleren. De tekst start met de woorden: "In deze vijd wan ongekende technologische ontwikkelingen en verwagende grenzen... ". Verder in de rede wordt melding gemaakt van de aanpassing wan het bedriffsleven aan nieuwe technische en economische ontwikkelingen. Voorts wordt er gezegd dat de gevolgen voor de informatiemaatschappij ingrijpend zijn en dat de traditionele verhoudingen veranderen en vragen om een nieuwe manier van leren en werken. Tot zover de troonrede. Uit deze passages kunnen we ICTaspecten destilleren. Doch, concrete maatregelen worden niet genoemd.

Wij, de academische wereld, zullen de regering dan ook kritisch blijven volgen op hetgeen echt ondernomen wordt.

Gelukkig zijn er ook positieve tekenen. Zo is er onlangs een fors bedrag gereserveerd voor de ontwikkeling van Gigapoort. Dit project is gericht op het realiseren van een hoogwardige ICT-infrastructuur met een aantal hoogwaardige diensten. Zowel wetenschappelijke instellingen als het bedrijfsleven zijn hierbij betrokken. De definitieve activiteiten moeten nog worden vastgesteld, maar het geheel geeft toch aan dat er serieus werk van wordt gemaakt.

Dit initiatief alleen is niet genoeg. We moeten zorgen dat er kennis van en inzicht in de ICT-architectuur wordt ontwikkeld. In de techniek kunnen wij namelijk nog vele ontwikkelingen verwachten. Het inzicht in de samenhang, de onderlinge relatie en de betekenis hiervan voor nieuwe ICT-toepassingen moet worden geborgd. Met name op de universiteiten zou hicraan, zoals ik al eerder aangaf, meer aandacht aan moeten worden besteed.

Er zijn dringend architecten nodig, aangezien zij het best in staat zijn om intermediair te zijn tussen de verschillende toepassers en de techniek. Het blijkt dat bij vooruitstrevende toepassers al snel de behoefte bestaat om een relatie te leggen met de technici. Dit pleit sterk voor een innige samenwerking in onderwijs en onderzoek tussen de ICT-technici en de brede groepen van toepassers. 
Wij moeten ook internationaal de handen ineenslaan. Immers, ICTontwikkelingen zijn naar hun aard internationaal. Elektrsche signalen urekken zich nu eenmaal niets aan van geografische grenzen.

Alertheid betreffende de daadwerkelijke invoering van ICT diensten bliff geboden. Zorgen dat de noodzakelijke kennis aanwezig is, is niet woldoende. Dat blijkt uit studies naar de redenen en omstandigheden waarin gegeven technische ontwikkelingen zich in bepaalde maarschappijen hebben voorgedaan (Mokyr, 1990). Als voorbeeld noem ik de uitvinding van de knoop. Ik doel hier op de knoop zoals we die op vele kledingstukken aantreffen. Deze knoop is in 1230 uitgevonden in het Centraal Duitse gebied. De technische kennis hiervoor was in grote delen van de wereld al geruime tijd voorhanden. Landen als China en Japan hadden een veel langere traditie op het gebied van fratie kledingstukken. Toch hebben deze landen de knoop niet uitgevonden.

Laten we dit voor ogen houden bij het stimuleren van ICT diensten, en laat het ons sterken in het hebben van een grote ambitie hierbij.

\section{De leerstoel: Telematica, in het bijzonder de ontwikkeling en invoering van telematica}

Nadat ik het veld van de ontwikkeling van ICT voor $u$ geschetst heb, wil ik u toelichten hoe ik mijn voornemens betreffende de invuling van mijn leerstoel gestalte ga geven. De omschrijving van deze leerstoel luidt: Telematica, in het bijzonder de ontwikkeling en invoering van telematica. De leerstoel is ondergebracht bij de capaciteitsgroep Informatica van de Faculteit der Algemene Wetenschappen van de Universiteit Maastricht. Het betreft een nieuwe leerstoel die onderdeel is van een nieuwe studierichting: kennistechnologie.

Deze studierichting is gebaseerd op een gezamenlijk voorstel van de Universiteit Maastricht en thet Limburgs Universitair Centrum in 
Dieperbeek, Belgie. Dit voorstel is in 1991 opgesteld en is goedgekeurd door zowel de Nederlandse als de Belgische overheid. Het is een transnationale studierichting die opleidr tot doctorandus in de Kennistechnologie. De studierichting loopt nu in haar vierde jaar.

Uit het rapport dat ten grondslag ligt aan de vorming van de studierichting blijkt duidelijk waarop deze zich richt.

Ik citeer:

"De studierichting Kenwistechnologie sluit aan bij de behoefte aan specifieke, beroepsgerichte opleidingen op het terrein vaw de moderne infornatietechnologie. De niewwe ontwikkelingen bivmen deze techwologie spelen een prownente rol bij overheid en bedrijfslevev. Zij worden gekenmerkt door beslisprocessen die gebaseerd zin op veelsoortige vormen van kennis. Kennisuchnologie richt zich dan ook op de wethodische integratie van de diverse aspecten wan kentis in praktische probleengebiedew". Einde citaat.

Men kan stellen dat de opstellers van de studie een wooruitziende blik hebben gehad. Tussen 1991 en nu is dit hele veld flink in beweging gekomen. De behoefte aan een dergelijke opleiding is groot. Het valkgebied ontwikkelt zich zeer snel. Op dit moment is telecommunicatie en telematica een onderdeel van het curriculum. De studie van $199 \rrbracket$ rept nog nauwelijks van deze disciplines.

Ontwikkelen en toepassen van Kennistechnologie kan de mogelijkheden van ICT echter niet meer buiten beschouwing laten. De communicatiecomponent is een inherent onderdeel van de informatiemaatschappij. Kennistechnologen kunnen daarbij een uitstekende rol vervullen in het slaan van een brug tussen de nieuwe mogelijkheden van de informatica in combinatie met de telematica, en de toepassingen op allerlei gebieden.

Mijn lecrstoel is alleteerst gericht op het creeren van inzicht in de telematica-architectur om zo ontwikkelingen te kunnen plaatsen. "Yypische en veel voorkomende bouwstenen in de telecommunicatie zullen daarbij aan de orde komen opdat men zinvolle combinaties van telecommunicatie en diensten kan maken. 
De komende jaren zal de invloed van de technische ontwikkelingen op de individuele bouwstenen groot zijn. In deze snel veranderende wereld moeten de kennistechnologen de juiste keuzen kunnen maken. Het creëren van inzicht in de samenhang binnen het ICT-gebied, is hier belangrijker dan het tot in detail bestuderen van technische verschijningswormen.

De doelstelling van de leerstoel is om de succesvolle ontwikkeling en invoering van telematica te bevorderen. Het onderzoek zal hierop gericht zijn. Daarbij zal ik expliciet samenwerking nastreven met het bedrifsleven en de universiteiten. Er moet snelheid gemaakt worden, en, zoals ik al eerder heb gesteld, samenwerking is hiervoor essentieel.

\section{Woorden van erkentelijkheid}

De universiteit Maastricht erkent samen met het Limburgs Universitair Centrum het belang van onderwijs en onderzoek in dienstontwikkeling op ICT-gebied. Men heeft daartoe samen met het Limburgs Universitair Centrum in Diepenbeek, België, een nieuwe studierichting Kennistechnologie ontwikkeld.

Mijn dank gaat uit naar het bestuur van de Stichting Wetenschapsbeoefening van de Universiteit Maastricht. Dat bestuur heeft mij benoemd tot deeltijdhoogleraar aan de Faculteit der Algemene Wetenschappen, in de Capaciteitsgroep Informatica. Deze levert een bijdrage aan de studierichting Kennistechnologie. Het bestuur heeft mij zodoende in de gelegenheid gesteld om ook buiten het bedriffsleven onderzoek te doen op het gebied van de Telematica. Graag spreek ik mijn dank uit aan het College van Bestuur van de Universiteit Maastricht voor mijn benoeming op deze leerstoell.

Ik ben ook de Raad van Bestuur van KPN erkentelijk voor de geboden gelegenheid om een deel van mijn tijd en energie te besteden aan onderwijs en onderzoek aan de Universiteit Maastricht en het Limburgs Universitair Centrum. 


\section{Hooggeleerde Boon, Beste Kasper,}

Ifk dank jou hartelijk voor het in mij gestelde vertrouwen. Ik geniet wan je creativiteit en je energie om deze transtationale studierichring Kennistechnologie vorm te geven en verder uit te bouwen. Met jouw instelling is her woor mij zeer motiverend hier een steentje aan te mogen bijdragen.

\section{Hooggeleerde Van den Herik, Beste Jaap,}

Wat cen energie steek jij in de werdere ontwikkeling van de capaciteitsgroep! Het is indrukwekkend te zien wat je allemaal onderneemt. Zeker als je datarbij in ogenschouw neemt dat dit niet ten koste gaat van het menselijk contact en de collegiale hulp.

Ik dank je uit de grond van mijn hart voor de steun en goede raad die je de afgelopen periode ook aan mij hebt gegeven. Ik ben onder de indruk van je kritische en logisch gestructurerende geest.

Jij kunt het nuttigen van geestelijk en aards voedsel perfect combineren. Het verorberen van een uitsmijter tijdens de lunch heeft voor mij cen nooit gedachte extra dimensie gekregen. Jaap, je bent cen betrouwbare en opbouwend kritische collega, ik verheug me in de verdere samenwerking met jou en je groep.

In de korte tijd die ik hier heb doorgebracht heb ik grote waardering opgevat voor jouw capaciteitsgroep. De bereidwilligheid tot wegwijs maken en ondersteunen dic men mij heeft betoond, is indrukwekkend. In het bijzonder bedank ik hierbij Leo Plugge en Jeroen Donkers die mij geweldig hebben geholpen bij het vormgeven en uirvoeren van mijn colllege. Bij Joke en Sabine woel ik mij zeer welkom.

\section{Hooggeleerde Flerackers, Beste Eddie,}

Dank voor jouw ideeën omtrent de invulling van het college. Ik heb de wijze van afstemming tussen onze vakken zeer prettig gevonden. Ook ben ik zeer onder de indruk van hetgeen bereikt is met het Expertisecentrum Digitale Media.

\section{Hooggeleerde Delamotte, Beste Wim,}

Dank voor de prettige en constructieve wijze van samenwerken bij het uitvoeren van het college en bijbehorend practicum. Her is zeer geruststellend en productief om zo'n goed geoutilleerd instituut als het Expentisecentrum Digitale Media in de buurt te hebben. 
Hooggeschatte Wit, Beste Cor,

Zonder jouw stem en rad was ik hier nooit getomen. Ik dank jo hartelijk voor het vertrouwen dat je in mij hebt gesteld tijdens je periode als directeur generaal wan thet Staatsbedrijf der $\mathbb{P} T \mathrm{TT}$ en voor je inspanningen bij het tot stand komen van mijn leerstoel. Wh heb weel van je geleerd. Nog steeds geniet ik van de contacten die we, zill het wat minder frequent, hebben. Ik ben onder de indruk van je wijsheid, je brede blikveld en je sociale capaciteiten.

\section{Hooggeleerde De Jong, Besite Cor,}

Vanaf deze plaats bedank ik je van harte voor het feit dat je me in 1985 wit het Dr Neher Laboratorium hebt weggellaald en me hebt voorgedragen als hoofd van de Beleids Advies Groep van de toenmalige PTT. Het heeft mijn blikveld geweldig verruimd. Bovendien waren er volop kansen om nieuwe zaken aan te pakken. Je hebt me de ruimte gegeven en me steeds kritisch benaderd. Het was een geweldige ervaring. Ik theb er veel van gelleerd.

\section{Collega's van KPN,}

Het feit dat ik hier sta heb ik mede te danken aan de geweldig stimulerende en open collegiale verhoudingen die ik in al mijn functies bij KPN heb mogen ondervinden. Tk voel me echt een product van die samenwerking. I $\mathrm{k}$ bewaar zeer prettige herinneringen aan vele pittige en ook wel late discussies rond allerlei thema's die KPN aangaan. Geweldig de wijze waarop we elkar onderling steunen ook als het wat moeilijker wordt.

\section{Moeder,}

Ik ben zeer blij dat je er hier vandaag bij kunt zijn. I $k$ heb altijd veel steun van je ondervonden tijdens mijn studic en daarna. Met dankbaarheid denk ik hier aan terug.

We denken op zo'n moment als dit onwillekeurig aan diegenen uit het gezin die er niet meer bij zijn. Zij zouden zonder twijfel ook van deze plechtigheid hebben genoten. 
Ria,

Mijn steun en toeverlaat. Je bent een geweldige echtgenote. Stimulerend als ik eens vast zit, meegenietend als het me eens lukt. Altijd sta je klaar en dat terwill je zelf ook drukke bezigheden hebt. Ook al wordt het niet altijd expliciet gezegd, i.k heb veel waardering en erkenning hiervoor!

Dames en Heren,

Ik dank u voor uw aandacht. 


\section{Referenties}

Experimentele transnationale studierichting Kennistechnologie

Rijksuniversiteit Limburg, Maastricht, Nederland

Limburgs Universitair Centrum, Diepenbeek, Belgie

Maastricht / Diepenbeek februari 1991

Het regeeraccoord 1998

Kabinetsformatie 1998

Tweede Kamer, vergaderjaar 1997-1998, 26024, nr. 10

De troonrede 1998

Verenigde vergadering van de Saten-Generaal in de Ridderzaal

Dinsdag 15 september 1998

\section{THE LEVER OF RICHES}

Technological Creativity and Economic Progress

Joel Mokyr

Oxford University Press

Shaping the Information Society

Eurescom, January 1995

Project P311

Gemeentelijke ICT projecten in VS en West-Europa

Intern rapport van KPN Research RA-98-30333

P.A.J. Tilanus

ICT en de Economie

eindrapport

Jan Willem Stumpel, Rick van der Linde

Beleidsstudies. Technologie Economie, nr 32 
Technologie Radar, deel $1 \mathrm{t} / \mathrm{m} 4$

Ministerie van Economische Zaken

maart 1998

Tak en functie van de ptt bezien in het licht wan de informatie- en telecommunicatetechnologie

Rapport van de Commissie Swarttouw

29 maart 1982

SIGNALEN VOOR STRAKS

een nieuwe richting voor de PTT

Commissie Steenbergen

juli 1985

ATHENA EN ARACHNE

Bestuurlijke patronen in de toepassing van netwerktechnologie

Dr. J.C.Arnbak

maart 1995 
